\title{
Utilization of Cottonseed Meal Supplemented with Iron for Detoxification of Gossypol in Nile Tilapia, Broodstock and their Impact on the Hatchability of their Progenies
}

\author{
Magdy M. Gaber ${ }^{1 *}$, Magdy M. Elhalfawy² and Amal M. Ramadan² \\ ${ }^{1}$ National Institute of Oceanography and Fisheries, Cairo, Egypt \\ ${ }^{2}$ National Institute of Oceanography and Fisheries, Suez, Egypt
}

\begin{abstract}
Nile tilapia broodstock fish of an initial average weight $72.3 \mathrm{~g}$ were stocked in 15 glass aquariums (500 L each) at 12 fish per aquarium were fed on cottonseed meal (40\% CSM) diets as a total replacement of fishmeal. The diets were supplemented with different levels of iron $\left(67,67,290,580\right.$ and $\left.870 \mathrm{mg} / \mathrm{kg} \mathrm{diet}^{-1}\right)$ and supplemented with methionine and lysine to be similar to control diet. The fish fed twice daily at a rate of $2 \%$ of the total fish biomass daily until the end of the experiment. The results showed that final fish weight, specific growth rate and number of larvae produced increased with increasing iron level and reached maximum when fish fed diet contained $40 \%$ CSM supplemented with $580 \mathrm{mg} \mathrm{Fe} \mathrm{kg} \mathrm{diet}^{-1}$ without causing, significant reduction in growth performance. In addition, the best results of larvae obtained from broad stock fed on diet contained 40\% CSM supplemented with $580 \mathrm{mg} \mathrm{Fe} \mathrm{kg}$ $\operatorname{diet}^{-1}$. Red blood cell count, hematocrit and hemoglobin were increased with increasing levels of iron and significantly affected by dietary iron. Apparent digestibility coefficients of protein, fat dry matter and energy were relatively high for most diets supplemented with iron and increased by increasing iron supplementation. There were no significant $(\mathrm{P}>0.05)$ differences among fish fed diets 1 (100\% FM) 4 and 5 which contained $100 \%$ CSM with additional 580 and $870 \mathrm{mg} \mathrm{Fe} \mathrm{kg} \mathrm{diet} \mathrm{supplemental} \mathrm{iron.} \mathrm{This} \mathrm{study} \mathrm{recommended} \mathrm{that} \mathrm{broodstock} \mathrm{fed} \mathrm{on} \mathrm{diet} \mathrm{contained} 40 \%$ CSM supplemented with $580 \mathrm{mg} \mathrm{Fe} \mathrm{kg} \mathrm{diet}^{-1}$ was comparable to fishmeal basal diet and have higher economic evaluation.
\end{abstract}

Keywords: Cottonseed; Iron; Brood stock; Nile tilapia

\section{Introduction}

Cottonseed meal (CSM) was ranks second to soybean meal in Egypt and less expensive than fishmeal and soybean meal per unit protein basis. Numerous studies have been conducted to determine the level of CSM that can be incorporated in Nile tilapia brood stock diets without affecting their growth performance [1-3]. Results have shown that the amount of CSM that can be included in Nile tilapia diets depends mainly on the levels of free gossypol and available lysine. El-Saidy [1] reported that repressed solvent extracted CSM could replace up to $50 \%$ of fishmeal in juvenile Nile tilapia diets without requiring lysine supplementation. Results Cheng et al. [4] suggest that $100 \%$ of SBM can be replaced by CSM with lysine supplement in diets contained $20 \%$ fish meal for Chinese Mitten Crab, Eriocheir sinensis without affecting growth performance and with decreasing level of ammonia released into the water. Free gossypol, when present in large quantity in the diet, it has shown to be toxic to monogastric animal including fish. Growth depression occurred in channel catfish fed diets counting more than $900 \mathrm{mg}$ free gossypol per $\mathrm{kg} \mathrm{diet}^{-1}$ [5]. Whereas a diet containing as low as $290 \mathrm{mg}$ free gossypol per $\mathrm{kg} \mathrm{diet}^{-1}$ reduced growth of rainbow trout [6]. In addition, gossypol is anti-carcinogenic activities [7,8]. Iron, as ferrous sulphate, was been successfully used to counteract the toxicity of free gossypol in diets of monogastric, terrestrial animals $[9,10]$. High levels of supplemental iron used to counteract the toxicity of gossypol may be harmful to fish because it was been suggested that a delicate balance exists between need of iron to sustain microbial growth. Sealey et al. [11] reported that high levels of dietary iron might lead to increased susceptibility of channel catfish to Edwardsiella ictaluri infection. Therefore, this study was be undertaken to evaluate the effects of total replacement of fishmeal protein by CSM protein supplemented with various levels of iron in practical diets on growth performance of Nile tilapia (Oreochromis niloticus L) broodstock.

\section{Materials and Methods}

\section{Experimental diets}

The experimental diets were formulated to contain $25 \%$ crude protein and $18828 \mathrm{~kJ}$ of gross energy $\mathrm{kg} \mathrm{diet}^{-1}$ based on feedstuff values reported by NRC (1993) [12]. The control diet (1) with $100 \%$ fishmeal protein and four diets (2-5) with 100\% CSM protein $(0.0145 \%$ free gossypol). Diets supplemented with iron from ferrous sulphate at 0.0 , 223, 513 and $803 \mathrm{mg} \mathrm{Fe} \mathrm{kg} \mathrm{diet}^{-1}$ for diets 2-5 respectively were prepared. Since the mineral premix contained $67 \mathrm{mg}$ iron as ferrous sulphate per $\mathrm{kg}$ diet, the total level of supplemental iron were $67,67,223,513$ and $803 \mathrm{mg} \mathrm{Fe} \mathrm{kg} \mathrm{diet}{ }^{-1}$. The experimental diets contained 0.0, 0.5, 1.0, and $1.5 \mathrm{mg}$ iron for each $\mathrm{mg}$ of free gossypol for diets $2-5$ respectively. The ingredients and chemical composition of the diets are shown in table 1.

\section{Experimental fish}

Nile tilapia (Oreochromis niloticus, L.) broodstock which obtained from (Saft khaled) Behira governorate of one year old with initial average weight $72.3 \pm 2.4 \mathrm{~g}$ were maintained on commercial diet until they selected, weighted and randomly distributed into 15 experimental glass tanks $(500 \mathrm{~L})$. Each tank was stocked in ratio of nine females

*Corresponding author: Magdy M. Gaber, National Institute of Oceanography and Fisheries, P. O. box 40, Shoubra, Cairo, Egypt, E-mail: gabermagdy@yahoo.com

Received July 12, 2012; Accepted September 24, 2012; Published October 04, 2012

Citation: Gaber MM, Elhalfawy MM, Ramadan AM (2012) Utilization of Cottonseed Meal Supplemented with Iron for Detoxification of Gossypol in Nile Tilapia, Broodstock and their Impact on the Hatchability of their Progenies. J Aquacult Res Dev 3:151 doi:10.4172/2155-9546.1000151

Copyright: (c) 2012 Gaber MM, et al. This is an open-access article distributed under the terms of the Creative Commons Attribution License, which permits unrestricted use, distribution, and reproduction in any medium, provided the original author and source are credited. 
Citation: Gaber MM, Elhalfawy MM, Ramadan AM (2012) Utilization of Cottonseed Meal Supplemented with Iron for Detoxification of Gossypol in Nile Tilapia, Broodstock and their Impact on the Hatchability of their Progenies. J Aquacult Res Dev 3:151 doi:10.4172/2155-9546.1000151

Page 2 of 5

\begin{tabular}{|c|c|c|c|c|c|}
\hline \multirow[t]{2}{*}{ Ingredients (\%) } & \multicolumn{5}{|c|}{ Diets } \\
\hline & 1 & 2 & 3 & 4 & 5 \\
\hline Fish meal (60\% C.P.) & 30.0 & - & -- & -- & - \\
\hline Cottonseed meal ( $41 \%$ C.P.) & - & 40.0 & 40.0 & 40.0 & 40.0 \\
\hline Yellow corn meal & 20.0 & 27.3 & 27.3 & 27.3 & 27.3 \\
\hline Wheat bran (14\% C.P.) & 30.0 & 30.0 & 30.0 & 30.0 & 30.0 \\
\hline Soybean oil & 5.0 & 5.0 & 5.0 & 5.0 & 5.0 \\
\hline Dicalcium phosphate & 2.0 & 2.0 & 2.0 & 2.0 & 2.0 \\
\hline Mineral and vitamin premix ${ }^{1}$ & 2.0 & 2.0 & 2.0 & 2.0 & 2.0 \\
\hline Molasses (as bender) & 2.0 & 2.0 & 2.0 & 2.0 & 2.0 \\
\hline L-Methionine & -- & 0.7 & 0.7 & 0.7 & 0.7 \\
\hline L-Lysine & -- & 1.0 & 1.0 & 1.0 & 1.0 \\
\hline $\begin{array}{l}\text { Supplemented iron mg kg diet }{ }^{-1} \\
\text { Proximate composition }(\%)^{2}\end{array}$ & -- & 0.0 & 225 & 513 & 803 \\
\hline Moisture & 6.21 & 6.13 & 6.14 & 6.46 & 6.48 \\
\hline Crude protein & 25.0 & 25.0 & 25.0 & 25.0 & 25.0 \\
\hline Crude fat & 11.94 & 11.9 & 11.98 & 11.82 & 11.8 \\
\hline Crude fiber & 7.3 & 7.2 & 7.1 & 7.2 & 7.2 \\
\hline Ash & 10.3 & 10.1 & 10.0 & 9.9 & 9.8 \\
\hline $\mathrm{NFE}^{3}$ & 39.25 & 39.67 & 39.78 & 39.62 & 39.72 \\
\hline Gross Energy (kj/g-1 diet) & 18.82 & 18.82 & 18.82 & 18.82 & 4.5 \\
\hline Fe supplemented $\left(\mathrm{mg} \mathrm{kg} \mathrm{diet}^{-1}\right)^{4}$ & 67.0 & 67.0 & 290 & 580 & 870 \\
\hline Free gossypol $\left(\mathrm{mg} \mathrm{kg} \mathrm{diet}^{-1}\right)^{5}$ & 00 & 580 & 580 & 580 & 580 \\
\hline Fe : gossypol ratio & 00 & $0.0: 1$ & $0.5: 1$ & $1: 1$ & $1.5: 1$ \\
\hline
\end{tabular}

${ }^{1}$ Premix supplied the following vitamins and minerals (according to Xie et al.)

${ }^{2}$ Values represent the mean of three sample replicates.

${ }^{3}$ Nitrogen free extract $(\mathrm{NFE})=\{100-($ moisture+crude protein+crude fat + ash +crude fiber)\}

${ }^{4} \mathrm{Fe}$-values include iron supplied by mineral premix

${ }^{5}$ Calculated from the free gossypol content of cottonseed meal.

Table 1: Ingredients and proximate compositions of diets containing cottonseed meal (CSM) supplemented with various levels of iron for Nile tilapia broodstock.

\begin{tabular}{|l|c|}
\hline Ingredients (\%) & Diet \\
\hline Fish meal (60 \% C.P.) & 37.5 \\
Soybean meal (44 \% C.P.) & 17.0 \\
Brewers dried yeast (44 \% C.P.) & 23.4 \\
Wheat bran & - \\
Starch & 13.0 \\
L-methionine & 1.0 \\
L- lysine & 0.5 \\
Vitamin/Mineral. Premix & 2.0 \\
Molasses & 2.0 \\
Vitamin C. & 0.1 \\
Fish oil & 3.0 \\
Cr2O3 & 0.5 \\
Proximate analysis (\%) & \\
Moisture & 13.3 \\
Crude protein & 41.5 \\
Crude fat & 12.3 \\
Ash & 6.6 \\
Crude fiber & 5.3 \\
NFE & 21.0 \\
Gross energy(kj g-1) & 19.25 \\
Cost (Egyptian pound) ${ }^{2}$ & 2.5 \\
\hline
\end{tabular}

${ }^{1} \mathrm{NFE}$ (Nitrogen free extract $)=100-(\%$ moisture $+\% \mathrm{C}$. protein $+\% \mathrm{C}$. fat $+\% \mathrm{C}$. fiber +ash)

2Price in Egyptian pound: 1.00=US $\$ 0.14$ based on 2005 exchange prices.

Table 2: Feed formulations and proximate composition of experimental diet used in feeding larvae (percentage on wet weight bases).

to three males. The fish were starved for one day prior to the start of experiment and five experimental diets namely 1-5 were assigned each to triplicate groups. Each group contained nine females' three males. When the females were ready for spawning about 5 days prior to spawning, the exiting males were used for mating in all treatment. The wire mesh between the males and females were removed after observing their courtship behavior. The day after spawning males were separated, returned to the original tanks. The eggs were collected from the female's buccal cavity and transferred to a strainer with, fine mesh, kept in plastic bowel containing dechlorinated water and aerated continuously. Every day, dead eggs were removed and halve of dechlorinated water in

each container replenished. The larvae from hatching to complete yolk sac from each treatment were counted and distributed into three glass aquaria $(100 \mathrm{~L})$ with total 15 glass aquaria were stocked with 200 larvae with an average weight $10 \pm 2 \mathrm{mg}$. The larvae were fed on a diet for one month (Table 2). The larvae were fed 6 days a week with a rate $10 \%$ of body weight until the end of experiment.

\section{The experimental setup}

During the experiment, the aquaria were supplied with fresh water about one-third of water volume in each aquaria was replaced daily by aerated fresh water after cleaning and removing the accumulated excreta. All aquaria were aerated. A photoperiod of $12 \mathrm{~h}$ light, $12 \mathrm{~h}$ dark (08:0020:00 hours) was used. The illumination was supplied by fluorescent ceiling light. Each group of fish was weight at the beginning and every 2 - week through the experimental period (12 weeks). The brood stocks were fed 6 days a week with a rate $2 \%$ of body weight until the end of experiment. At the end of experiment three fish from each group (nine fish per each treatment) was killed homogenized and frozen. During last month, feces were collected from each aquarium every morning before feeding. The feces were collected on filter paper for drying and subsequent chemical analysis. The apparent digestibility coefficients (ADCs) for protein, lipid, dry matter and energy were calculated using the formula of Maynard and Loosli [13]. The ADC=100x [1-(\%dietary $\mathrm{Cr}_{2} \mathrm{O}_{3} / \%$ fecal $\mathrm{Cr}_{2} \mathrm{O}_{3}$-\%fecal nutrient/\%dietary nutrient)]

\section{Hematological assay}

Blood samples were obtained from broodstock at the end of experimental period. Four fish per group were randomly chosen and anaesthetized with tricainemethanesulphonate (MS-222, Argent Chemical Redmond, WA, USA) at $125 \mathrm{mg} \mathrm{L}^{-1}$. Blood samples were collected from the caudal vein using heparinized 27- gauge needles and tuberculin syringes $\left(20 \mathrm{Um} \mathrm{L}^{-1}\right)$ for determination of hematocrit (Ht), red blood cell count (RBC) and hemoglobin ( $\mathrm{Hb})$. Hematocrit was determined using the micro-Ht method described by Brown [14]. Total RBCs were determined by diluting whole blood and enumeration in hemocytometer. Hemoglobin was determined using the total Hb kit (Sigma Diagnostics, Sigma, St Louis, MO, USA) which is standardized procedure using the cyanomethemoglobin method.

\section{Chemical analyses}

Analysis of samples was made as follows: dry matter after desiccation in an oven $\left(105^{\circ} \mathrm{C}\right.$ for $24 \mathrm{~h}$ ); ash (incineration at $550^{\circ} \mathrm{C}$ for $12 \mathrm{~h}$ ); crude protein (microkjeldahil, $\mathrm{N} \times$ 6.25); crude lipid (ether extract using soxhlet method) crude fiber (AOAC 1995) and gross energy (Ballistic bomb calorimeter, Gallenkamp, UK). The chromic oxide in diets and

\begin{tabular}{|l|l|l|l|l|c|}
\hline Parameters & \multicolumn{5}{|c|}{ Diets } \\
\cline { 2 - 6 } & 1 (control) & 2 & 3 & 4 & 5 \\
\hline FBW $^{1}$ & $170.6 \pm 2.2^{\mathrm{b}}$ & $151.8 \pm 2.5^{\mathrm{d}}$ & $161.3 \pm 4.2^{\mathrm{c}}$ & $180.7 \pm 5.8^{\mathrm{a}}$ & $171.2 \pm 3.1^{\mathrm{b}}$ \\
\hline FI (g fish-1) & $151.7 \pm 0.3^{\mathrm{ab}}$ & $146.2 \pm 0.8^{\mathrm{c}}$ & $146.1 \pm 0.1^{\mathrm{c}}$ & $154.5 \pm 0.1^{\mathrm{a}}$ & $150.7 \pm 0.1^{\mathrm{b}}$ \\
\hline SGR (\%/day) & $1.02 \pm 0.1^{\mathrm{b}}$ & $0.9 \pm 0.1^{\mathrm{c}}$ & $0.9 \pm 0.1^{\mathrm{c}}$ & $1.1 \pm 0.1^{\mathrm{a}}$ & $1.02 \pm 0.04^{\mathrm{b}}$ \\
\hline FCR (FI/WG) & $1.54 \pm 0.1^{\mathrm{a}}$ & $1.92 \pm 0.03^{\mathrm{d}}$ & $1.82 \pm 0.1^{\mathrm{c}}$ & $1.67 \pm 0.1^{\mathrm{b}}$ & $1.73 \pm 0.1^{\mathrm{bc}}$ \\
\hline PER5 & $2.58 \pm 0.1^{\mathrm{ab}}$ & $2.16 \pm 0.1^{\mathrm{c}}$ & $2.42 \pm 0.1^{\mathrm{b}}$ & $2.8 \pm 0.2^{\mathrm{a}}$ & $2.6 \pm 0.1^{\mathrm{a}}$ \\
\hline
\end{tabular}

Values are mean \pm standard deviation. Values in the same row with same superscripts are not significantly different $(P \geq 0.05)$.

${ }^{1} \mathrm{FBW}=$ final body weight

${ }^{2} \mathrm{FI}=$ feed intake.

${ }^{3} \mathrm{SGR}$, specific growth rate $=(\mathrm{Ln}$ FBW-Ln IBW $) / 90 \times 100$

${ }^{4} \mathrm{FCR}$, feed conversion ratio=dry feed fed/ body weight gain.

PER, protein efficiency ratio $=$ final body weight gain/protein intake $X 100$.

Table 3: Growth performance and nutrient utilization of Nile tilapia Broodstock fed the experimental diets. 
feces was determined using the method of Zhou et al. (2004). Gossypol content of CSM was analyzed using standard method of American oil chemists (AOCS 1998) [15].

\section{Water quality}

Water temperature and dissolved oxygen were measured every other day using an YSI Model 58 oxygen meter (Yellow Springs Instrument, Yellow Springs, OH, USA). Total ammonia and nitrite were measured twice weekly using a DREL, 2000 spectrophotometer (Hash Company, Loveland, CO, USA). Total alkalinity and chloride were monitored twice weekly using the titration method; $\mathrm{pH}$ was monitored twice weekly using an electronic $\mathrm{pH}$ meter ( $\mathrm{pH}$ pen; Fisher Scientific, Cincinnati, OH, USA). During the 30 -week feeding trial, the waterquality parameters averaged $( \pm \mathrm{SD})$ : water temperature, $27.6 \pm 0.9^{\circ} \mathrm{C}$; dissolved oxygen, $6.5 \pm 0.5 \mathrm{mg} \mathrm{L}^{-1}$; total ammonia, $0.18 \pm 0.14 \mathrm{mg} \mathrm{L}^{-1}$; nitrite, $0.07 \pm 0.05 \mathrm{mg} \mathrm{L}^{-1}$; total alkalinity, $183 \pm 45 \mathrm{mg} \mathrm{L}^{-1}$; chlorides, $573 \pm 150 \mathrm{mg} \mathrm{L}^{-1} ; \mathrm{pH}, 7.9 \pm 0.2$.

\section{Calculations and Statistical Analysis}

Calculations of growth parameters followed those described in a previous work [16]. Data were analyzed using analysis of variance (ANOVA) using the SAS ANOVA procedure (Statistical Analysis System 1988). Duncan's multiple range tests was used to compare differences among individual means. Treatment effects were considered significant at $\mathrm{P}<0.05$. All percentage and ratio were transformed to arcsin values prior to analysis [17].

\section{Results}

The results of average final body weight (FBW) specific growth rate (SGR) food conversion (FCR) and protein efficiency ratio (PER) are presented in table 3. At the start experiment (broodstock) there were no significant difference $(\mathrm{P}>0.05)$ in average body weight which indicates that there were homogeneity among these groups. At the end of the experiment, the average FBW and SGR showed that the groups of fish fed diet 2 contained $40 \%$ CSM without iron supplement had the lowest value of FBW and SGR, when compared with groups of fish fed control diet 1 (100\% FM protein). In addition, when compared with GSM-based diets (4-5) supplemented with iron at rat of 580 and 870 $\mathrm{mg} \mathrm{Fe} / \mathrm{kg}$ respectively. Among diets containing CSM, the response of fish to increasing levels of dietary iron above $580 \mathrm{mg} \mathrm{Fe} \mathrm{kg} \mathrm{diet}^{-1}$ there were no liner increase in FBW and SGR. Mean body weights of fish are shown in figure 1. Nile tilapia growth rates began to differ in week 6 and became distinctly different between weeks 8 and 12. Groups of fish fed diet 4 (40\% CSM supplemented with $\left.580 \mathrm{mg} \mathrm{Fe} \mathrm{kg} \mathrm{diet}{ }^{-1}\right)$

\begin{tabular}{|c|c|c|c|c|c|}
\hline \multirow[t]{2}{*}{ Parameters } & \multicolumn{5}{|c|}{ Treatments } \\
\hline & 1 (control) & 2 & 3 & 4 & 5 \\
\hline FBW $^{1}$ & $7.2 \pm 07^{a}$ & $4.5 \pm 0.1^{c}$ & $5.8 \pm 0.1^{b}$ & $7.1 \pm 0.5^{\mathrm{a}}$ & $6.5 \pm 0.6 a^{b}$ \\
\hline DGR $\left(\% \text { day }^{-1}\right)^{2}$ & $23.9 \pm 2.1^{\mathrm{a}}$ & $14.9 \pm 0.4^{c}$ & $19.3 \pm 0.3^{b}$ & $23.6 \pm 1.7^{\mathrm{a}}$ & $21.4 \pm 2.4^{\mathrm{ab}}$ \\
\hline $\mathrm{FI}\left(\mathrm{g} \mathrm{fish}^{-1}\right)^{3}$ & $14.1 \pm 0.2^{\mathrm{a}}$ & $11.5 \pm 0.4^{c}$ & $12.1 \pm 0.3^{b}$ & $13.9 \pm 0.3^{a}$ & $12.4 \pm 0.4^{b}$ \\
\hline FCR $(\mathrm{FI} / \mathrm{WG})^{4}$ & $2.0 \pm 0.2^{\mathrm{b}}$ & $2.6 \pm 0.1^{\mathrm{a}}$ & $2.1 \pm 0.1^{\mathrm{b}}$ & $2.0 \pm 0.1^{\mathrm{b}}$ & $1.9 \pm 0.1^{b}$ \\
\hline PER $^{5}$ & $1.25 \pm 0.1^{\mathrm{a}}$ & $1.0 \pm 0.02^{c}$ & $1.19 \pm 0.04^{b}$ & $1.27 \pm 0.06^{\mathrm{a}}$ & $1.9 \pm 0.1^{\mathrm{a}}$ \\
\hline Survival (\%) & $85.4 \pm 1.3$ & $71.4 \pm 1.4$ & $71.9 \pm 1.1$ & $84.2 \pm 2.1$ & $74.3 \pm 3.4$ \\
\hline
\end{tabular}

Values are mean \pm standard deviation. Values in the same row with same superscripts are not significantly different $(P \geq 0.05)$.

${ }^{1} \mathrm{FBW}=$ final body weight.

${ }^{2} \mathrm{DGR}$, daily growth rate=final body weight gain $/ 30 \times 100$

${ }^{3} \mathrm{FI}=$ feed intake.

${ }^{4} \mathrm{FCR}$, feed conversion ratio=dry feed fed/body weight gain

${ }^{5} \mathrm{PER}$, protein efficiency ratio=final body weight gain/protein intake $\mathrm{X} 100$.

Table 4: Growth performance and nutrient utilization of Nile tilapia larvae fed the experimental diets.

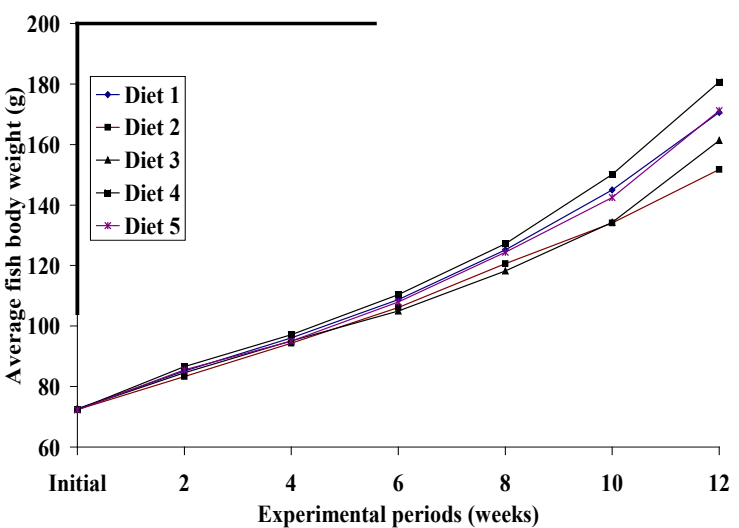

Figure 1: Effect of total replacement of fishmeal with cottonseed meal supplemented with different levels of iron on growth of Nile tilapia Broodstock.

\begin{tabular}{|l|c|c|c|c|c|}
\hline \multirow{2}{*}{ Parameters } & \multicolumn{5}{|c|}{ Treatments } \\
\cline { 2 - 6 } & 1 (control) & 2 & 3 & 4 & 5 \\
\hline Dry mater & $74.0 \pm 0.6^{\mathrm{a}}$ & $63.8 \pm 0.6^{\mathrm{e}}$ & $65.1 \pm 0.8^{\mathrm{d}}$ & $72.0 \pm 0.2^{\mathrm{c}}$ & $73.2 \pm 0.1^{\mathrm{b}}$ \\
\hline Protein & $86.1 \pm 0.3^{\mathrm{ab}}$ & $76.5 \pm 0.5^{\mathrm{d}}$ & $78.7 \pm 0.4^{\mathrm{c}}$ & $86.4 \pm 0.2^{\mathrm{a}}$ & $86.4 \pm 0.2^{\mathrm{a}}$ \\
\hline Fat & $78.0 \pm 0.4^{\mathrm{a}}$ & $62.4 \pm 0.6^{\mathrm{d}}$ & $63.8 \pm 0.8^{\mathrm{c}}$ & $77.2 \pm 0.6^{\mathrm{a}}$ & $78.4 \pm 1.1^{\mathrm{a}}$ \\
\hline Energy & $76.7 \pm 0.6^{\mathrm{c}}$ & $60.1 \pm 0.3^{\mathrm{c}}$ & $60.4 \pm 0.7^{\mathrm{c}}$ & $70.3 \pm 0.9^{\mathrm{ab}}$ & $72.1 \pm 0.1^{\mathrm{a}}$ \\
\hline
\end{tabular}

Values are mean \pm standard deviation. Values in the same row with same superscripts are not significantly different $(P \geq 0.05)$.

Table 5: Apparent digestibility of dry matter, fat, protein, and energy for Nile tilapia broodstock fed the experimental diets.

\begin{tabular}{|l|l|l|l|l|l|}
\hline \multirow{2}{*}{ Parameters } & \multicolumn{5}{|c|}{ Diets } \\
\cline { 2 - 6 } & $1($ Control) & 2 & 3 & 4 & 5 \\
\hline $\mathrm{Ht}(\%)$ & $74.0 \pm 0.6^{\mathrm{a}}$ & $63.8 \pm 0.6^{\mathrm{e}}$ & $65.1 \pm 0.8^{\mathrm{d}}$ & $72.0 \pm 0.2^{\mathrm{c}}$ & $73.2 \pm 0.1^{\mathrm{b}}$ \\
\hline $\mathrm{Hb}(\mathrm{mg} / \mathrm{ml})$ & $86.1 \pm 0.3^{\mathrm{ab}}$ & $76.5 \pm 0.5^{\mathrm{d}}$ & $78.7 \pm 0.4^{\mathrm{c}}$ & $86.4 \pm 0.2^{\mathrm{a}}$ & $86.4 \pm 0.2^{\mathrm{a}}$ \\
\hline $\mathrm{RBC}\left(10^{9} / \mathrm{ml}\right)$ & $78.0 \pm 0.4^{\mathrm{a}}$ & $62.4 \pm 0.6^{\mathrm{d}}$ & $63.8 \pm 0.8^{\mathrm{c}}$ & $77.2 \pm 0.6^{\mathrm{a}}$ & $78.4 \pm 1.1^{\mathrm{a}}$ \\
\hline
\end{tabular}

Values are mean \pm standard deviation. Values in the same row with same superscripts are not significantly different $(P \geq 0.05)$.

Table 6: Blood parameters for Nile tilapia Broodstock fed the experimental diets.

had significantly $(\mathrm{P}<0.05)$ the best values FCR and PER, the poorest result were recorder with groups of fish fed diet 2 (100\% CSM protein) without additional iron. Larvae growth performance is represented in table 4. It showed that the larvae obtained from broad stock fed on diets 4 and 5 supplemented with 580 and $875 \mathrm{mg} \mathrm{Fe} \mathrm{kg} \mathrm{diet}^{-1}$ have growth comparable to larvae obtained from broodstock fed on control diet significantly $(\mathrm{P}<0.05)$ higher than the larvae obtained from broad stock fed on other diets. The result ADCs of protein, fat, dry matter and energy for Nile tilapia fed experimental diets are presented in table 5. Apparent digestibility coefficients of protein, fat, dry mater and energy were relatively high for most treated diets with iron and increased with increasing level of iron. There were no significant differences $(\mathrm{P}>0.05)$ among groups of fish fed control diet $(100 \% \mathrm{FM})$ and diet 5 (which contained 100\% CSM with additional $803 \mathrm{mg} \mathrm{Fe} \mathrm{kg} \mathrm{diet)} \mathrm{for} \mathrm{protein}$ fat and energy ADC. Blood parameters of Nile tilapia broodstock fed experimental diets are illustrated in table 6. Hematocrit \% (Ht), $\mathrm{Hb}$ and RBCs were increased with increasing level of iron and significantly affected by dietary iron and not differ significantly $(\mathrm{P}<0.5)$ when compared with control diet contained $100 \%$ FM protein. Wholebody moisture, crude protein, crude fat and energy content were not significantly influenced by dietary treatments. The results of wholebody proximate analysis, expressed on a wet basis $\%$, for Nile tilapia fed experimental diets averaged $( \pm S D)$ : moisture, $76.4 \pm 0.3$; crude protein, $15.0 \pm 0.2$; crude fat, $4.7 \pm 0.3$; energy content $508.8 \pm 14.1 \mathrm{kj}$ 


\begin{tabular}{|c|c|c|c|c|c|}
\hline \multirow[t]{2}{*}{ Item } & \multicolumn{5}{|c|}{ Diets } \\
\hline & 1 (control) & 2 & 3 & 4 & 5 \\
\hline No. fish stocked $/ \mathrm{m}^{3}$ & 24 & 24 & 24 & 24 & 24 \\
\hline No fish harvested $/ \mathrm{m}^{3}$ & 24 & 24 & 24 & 24 & 24 \\
\hline Harvested $\left(\mathrm{kg} / \mathrm{m}^{3}\right)$ & 4.1 & 3.6 & 3.9 & 4.3 & 4.1 \\
\hline Food used $\left(\mathrm{kg} / \mathrm{m}^{3}\right)$ & 3.6 & 3.5 & 3.5 & 3.71 & 3.62 \\
\hline Fingerling cost (LE) ${ }^{1}$ & 24 & 24 & 24 & 24 & 24 \\
\hline Food cost $(\text { LE) })^{2}$ & 18.0 & 5.3 & 5.3 & 5.6 & 54 \\
\hline No. of larvae harvested $/ \mathrm{m}^{3}$ & 4166 & 2250 & 2746 & 4122 & 4120 \\
\hline Fish cost $(\mathrm{LE})^{1}$ & 42 & 29.3 & 29.3 & 29.6 & 29.4 \\
\hline Larvae cost/(LE) ${ }^{1}$ & 104 & 56.3 & 68.7 & 103.3 & 103 \\
\hline Total cost $(\mathrm{LE})^{1}$ & 41 & 36 & 39 & 43 & 41 \\
\hline Value of harvest (8.6LE. $\mathrm{kg}^{-1}$ ) & 145 & 92.3 & 107.7 & 146.3 & 144 \\
\hline Net profit (LE) ${ }^{1}$ & 103 & 63 & 78.4 & 116. & 114.6 \\
\hline
\end{tabular}

'LE= Lever Egyptian, one Dollar equal 6.12 LE.

${ }^{2}$ Food cost equal 2.80 and 2.25 LE for diets.

Table 7: Economic information of Nile tilapia Broodstock.

$\left(100 \mathrm{~g}^{-1}\right)$; crude ash $3.5 \pm 0.4$. There was a significant $(\mathrm{P}<0.05)$ change in ash content associated with diets supplemented with different levels of iron. The economic calculation from the study is presented in table 7. The feed cost and the total cost (Lever Egyptian) increased with fish fed fishmeal protein (Diet 1). From the economic information, it can be concluded that the highest net profit was achieved with fish fed diets that contained 40\% CSM supplemented with $580 \mathrm{mg}$ Fe kg diet.

\section{Discussion}

Early studies have indicated that the amount of CSM that can be used in Nile tilapia feed depends mainly on the level of free gossypol and available lysine content of the meal. Due to unfavorable physiological effects of gossypol lead to a reduction in the biological availability of lysine because of the binding properties of gossypol. Ofojekwu and Ejike [18] found that O. aurous fed CSM-based diets yielded poor performance. The authors attributed the poor performance to the gossypol contained in glanded and glandless CSM respectively. On the contrary, solvent extracted CSM was successfully used as single dietary protein source for O. mossambicus [19] and Nile tilapia [2,20]. Also El-Saidy and Gaber [20] reported that CSM supplemented with iron was successfully used as single dietary protein for Nile tilapia fry. In the present study, regardless of supplemental levels of iron, fish fed diets that contained 40\% CSM (580 mg free gossypol) supplemented with lysine to a level equal that of the FM diet and supplemented with $580 \mathrm{mg}$ Fe kg diet exhibited better FBW and SGR than those fed diet 2 (40\% CSM without additional iron) in feeding broad stock. This may be addition of iron sulphate at weight ratio of 1:1 of iron to free gossypol, which lead to improving their performance diet 4 (Table 1). Although a diet contained 40\% CSM (diet) supplemented with lysine and 223 mg iron, it did net improve fish performance Robinson and Rawles [21] showed that supplementation of lysine to diet containing $44.6 \%$ glandless cottonseed flour or $44.4 \%$ glandless CSM as total replacement of soybean meal (SBM) did not improved growth and feed conversion. However when glanded CSM with $0.022 \%$ free gossypol was used to totally replace SBM, supplementation of lysine is, need to improve the nutritional value channel catfish feed to be level comparable with that of control [22]. Also El-Saidy and Gaber [20] reported that adding 972 $\mathrm{mg}$ Fe Kg diet ${ }^{-1}$ from ferrous sulphate CSM-based diet that contained $972 \mathrm{mg}$ free gossypol for Nile tilapia reduced the negative effects of gossypol and improved growth performance. In our study even though methionine and lysine were added total replacement of FM with CSM (0.145\% free gossypol) without additional iron (2) resulted in reduced FBW and SGR. The higher concentration of free gossypol in CSM in our study may account for difference between results of this study and that of Robinson [22]. The response of broad stock to larval production was influenced by supplemental levels of dietary iron. For diet 1 containing no CSM (FM-based diet), there was an increase in larval production. When FM was totally replaced by CSM (40\%), the diets 4 -

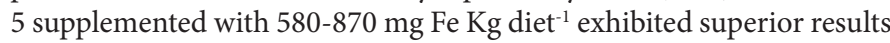
and comparable to the control diet. Our results are agreement with those of Rojes and Scolt, Wedegaertner, Jones, Martin, El-Saidy and Gaber $[9,10,20,23,24]$. They found that addition of iron sulphate at weight ratio of 1:1 of iron to free gossypol in pigs, broilers and Nile tilapia was effective in reducing the toxicity of free gossypol and improving animal performance. They suggested that iron inactivates gossypol by forming a strong complex compound in the intestinal tract thus preventing it from absorbed [24]. Result of the present study indicate that of larvae of female fish of Nile tilapia significant influenced with iron supplement and the lowest value we recorded with group of fish fed diet $2(100 \%$ CSM without iron supplementation. The same results were reported by Dabrowski et al. [8], Bloom et al. [7] and Rinchard et al. [25] in their studies on rainbow trout fish. The present, study showed that ADC value of nutrients in CMS was comparable with those in other oil seed meals. El-Saidy and Gaber [20] reported ADC of crude protein in CSM was $78.7-88.9 \%$ for Nile tilapia when supplemented with methionine and lysine. Cheng and Hardy [4] found the ADC of protein in CSM was 81.6-87.9\% for rainbow trout. These values agree of our results where digestibility of crude protein in CSM-based diets ranged from $76.5 \%$ to $88.2 \%$. The results also in agreement with Mbahinzireki et al. [3], where reported that ADCs of crude protein decreased as dietary gossypol level increased in tilapia (Oreochromis sp). The response of broodstock based on RBC. He and $\mathrm{Hb}$ to dietary CSM were influenced by supplemental levels of dietary iron. For diets containing no CSM (FM based diets), there was an increase in these parameters. When FM was totally replaced by CSM (40\%) the diets 4, 5 supplemented with 580 and 870 $\mathrm{Fe} \mathrm{Kg} \mathrm{diet}{ }^{-1}$ exhibited superior results of $\mathrm{Ht}, \mathrm{Hb}$ and $\mathrm{RBC}$ to fish meal diet. Our results are in agreement with those of Martin [10] in catfish. On the Contrary to our results of the hematological values with Nile tilapia in the present study, Barros, Lime and Klesius [26] reported that channel catfish fed a diet containing 50\% CSM supplemented with 671

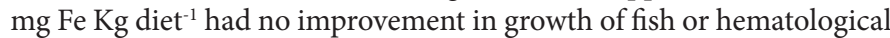
values with treatments without diet iron added. They attributed that to diets high in CSM contain compounds or factors, which reduce from iron absorption or availability. Also, Results of study Nguyen et al, [27] indicated that cotton seed meal and soybean meal could totally replace FM's inclusion rate in commercial diets for juvenile tilapia. Furthermore, methionine did not appear to be limiting in practical diets using typical levels of CSM, DSESM, and MBM as primary protein sources. Production estimated, in the present experiment are based on biomass estimates which adjusted for mortality and corrected for growth rate [28]. It is the basis for estimating economic yield for both fish culture operation and for natural fish population. Because production and harvest value were dependent on protein, source. In addition, final harvest and production values were directly related to protein source and iron supplemental level at which growth rate is reduced and when it occurs, production will be reduced. The critical level in our experiment was fish fed diets that contained 40\% CSM supplemented with $580 \mathrm{mg}$ Fe kg diet exhibited maximum growth in broodstock of Nile tilapia. Results of these studies indicate that total replacement of FM with CSM ( $0.145 \%$ free gossypol) reduced the nutritional value of the diets. For CSM containing diets, supplemented with iron, as ferrous sulphate at 1:1 ratio of iron to free gossypol, had no effects on the nutritional value of the diets. In addition iron presents in practical diets at a level of 2 $\mathrm{mg}$ Fe kg diet 5 appears to sufficient to maintain normal function of growth performance, feed utilization and biological and hematological parameters of Nile tilapia. 
Citation: Gaber MM, Elhalfawy MM, Ramadan AM (2012) Utilization of Cottonseed Meal Supplemented with Iron for Detoxification of Gossypol in Nile Tilapia, Broodstock and their Impact on the Hatchability of their Progenies. J Aquacult Res Dev 3:151 doi:10.4172/2155-9546.1000151

Page 5 of 5

\section{References}

1. El-Saidy DMSD (1999) Evaluation of cottonseed meal as partial and complete replacement of fishmeal in practical diets of Nile tilapia (Oreochromis niloticus) fingerlings. Egyptian Journal of Aquatic Biology and Fisheries 3: 441-457.

2. El-Sayed AFM (1999) Alternative dietary protein sources for farmed tilapia, Oreochromis spp. Aquaculture 179: 149-168

3. Mbahinzireki GB, Dabrowski KJ, EL-Saidy D, Wisner ER (2001) Growth, feed utilization, and body composition of tilapia (Oreochromis sp.) fed cottonseed meals-based diets in a recirculating system. Aquacul Nut 7: 189-200.

4. Cheng ZJ, Hardy RW (2002) Apparent digestibility coefficients and nutritional value of cottonseed meal for rainbow trout (Oncorhynchus mykiss). Aquaculture 212: 361-372.

5. Dorsa WJ, Robinette HR, Robinson EH, Poe WE (1982) Effects of dietary cottonseed meal and gossypol on growth of young channel catfish. Transactions of the American Fisheries Society 111: 651-655.

6. Herman RL (1970) Effect of gossypol on rainbow trout Salmo gairdner Richardson. J Fish Biol 2: 293-304.

7. Bloom JH, Lee KJ, Rinchard J, Dabrowski K, Ottobre J (2001) Reproduction efficiency and maternal-offspring transfer of gossypol in rainbow trout (Oncorhynchus mykiss) fed diets containing cottonseed meal. J Anim Sci 79: $1533-1549$.

8. Dabrowski K, Lee KJ, Rinchard J, Ciereszko A, Blom JH, et al. (2001) Gossypo isomers bind specifically to blood plasma proteins and spermatozoa of rainbow trout fed diets 279 containing cottonseed meal. Biochim Biophys Acta 1525: $37-42$

9. Jones LA (1987) Recent advances in using cottonseed products. Proceedings of the Florida Nutrition Conference, 12-13 March 1987, pp.119-138. Daytona Beach, FL, USA

10. Martin SD (1990) Gossypol effects in animal feeding can be controlled. Feedstuffs 62: 14-17

11. Sealey WM, Lim C, Klesius PH (1997) Influence of the dietary level of iron from iron methionine and iron sulfate on immune response and resistance of channel catfish to Edwardsiella ictaluri. J World Aquaculture Society 28: 142-149.

12. National Research Council (1993) Nutrient Requirements of Warm Water Fishes and Shellfishes. National Academy of Sciences, Washington, DC, USA, 102

13. Maynard LA, Loosli JK (1969) Animal Nutrition, 6th ed. McGraw Hill, New York USA.

14. Brown BA (1988) Routine hematology procedures. In: Hematology: Principles and Procedures, ed. by B.A. Brown, pp. 7-122. Leo and Febiger, Philadelphia, $P$ A, USA.

15. AOCS (American Oil Chemists Society) (1998) Official Methods and Recommended Practices of the American Oil Chemists Society, 1997, (5thedn). American Oil Chemists Society, Champaign, IL, USA.

16. El-Saidy DMSD, Gaber MMA (2002) Complete replacement of fishmeal by soybean with the dietary L-lysine supplementation in Nile tilapia fingerlings. J World Aquaculture Society 33: 297-306.

17. Zar JH (1999) Bio-Statistical Analysis, 2nd edn. Prentice- Hall International, Englewood Cliffs, NJ, USA, 663

18. Ofojekwu PC, Ejiike C (1984) Growth response, and feed utilization in tropical cichlid Oreochromis niloticus (Lin) fed on cottonseed-based artificial diets. Aquaculture 42: 27-36.

19. Jackson AJ, Capper BS, Matty AJ (1982) Evaluation of some plant proteins in complete diets for the tilapia, Sarotheroden mossambicus. Aquaculture 27 : 97-109.

20. El-Saidy DMSD, Gaber MMA (2004) Use of cottonseed meal supplemented with iron for detoxification of gossypol as a total replacement of fishmeal in Nile tilapia, Oreochromis niloticus (L.) diets. Aquaculture Research 35: 859-865.

21. Robinson EH, Rawles SD (1983) Use of defatted, glandless cottonseed flour and meal in channel catfish diets. In: Proceedings of Annual Conference of Southeastern Association of Fish and Wildlife Agencies 37: 358-363.

22. Robinson $\mathrm{EH}$ (1991) Improvement of cottonseed meal protein with supplement lysine in feed for channel catfish. Journal of Applied Aquaculture 1: 1-14.
23. Rojas SW, Scott ML (1969) Factor affecting the nutritive value of cottonseed meal as protein source in chick diets. Poult Sci 48: 819-835.

24. Wedegaertner TC (1981) Making the most cottonseed meal. Feed Management Magazine 32: 13

25. Rinchard J, Lee KJ, Czesny S, Ciereszko A, Rinchard J, et al. (2003) Effect of feeding cottonseed meal containing diets to broodstock rainbow trout and their impact on the growth of their progenies. Aquaculture 227: 77-87.

26. Barros MM, Lim C, Klesius PH (2002) Effect of soybean meal replacement by cottonseed meal and iron supplementation on growth, immune response and resistance of channel catfish (Ictalurus punctatus) to Edwardsiella ictaluri challenge. Aquaculture 207: 263-279.

27. Nguyeni TN, Allen D, Saoud PI (2009) Evaluation of Alternative Protein Sources to Replace Fish Meal in Practical Diets for Juvenile Tilapia, Oreochromis spp. Journal of the World Aquaculture Society 40: 113-121.

28. Chapman, DW (1968) Methods for Assessment of Fish Production in Fresh Water, In: S. D. Gerking, International Biology Programmer Handbook No. 3 : 